\title{
IMPLEMENTASI GAYA KEPEMIMPINAN MENGGUNAKAN TIPE PATERNALISTIK DALAM MENINGKATKAN SUMBER DAYA MANUSIA
}

\author{
( Study Kasus Wisata Eco Park Desa Bremi Kabupaten Probolinggo) \\ Melisa Srimurty Aprilia, Intan Alvionita, Misbahul Khoiri, Moch. Fanil Abrori \\ dan Yunita Amalia \\ Jurusan Administrasi Publik, \\ Fakultas Ilmu Sosial Dan Ilmu Politik, Universitas Panca Marga Probolinggo \\ Universitas Panca Marga Probolinggo
}

\begin{abstract}
This study aims to support and study the role of leaders in improving Desa Bremi in social psychology. The style or style of a leader greatly influences his followers or subordinates. The type or style of a paternalistic leader is a leader who uses or applies to perceptions, values held, attitudes and protections seen in needs. Desa bremi is a village located in District Krucil of Probolinggo Regency, East Java, which is expected to be able to provide quality human resources. As a leader in the village Bremi made efforts to be able to direct $H R$ well from the problem of HR development. This study used a qualitative descriptive study using a sample technique of 4 respondents using interviews and observation and documentation. From this sample the researchers chose from the village apparatus, one RT / RW chairman and 2 villagers.
\end{abstract}

Keywords: Role, Style-Type, Leader, Human Resources, Village. 


\section{Pendahuluan}

Kepemimpinan dikatakan sebagai proses mengarahkan dan mempengaruhi aktivitas-aktivitas yang ada hubungannya dengan perkerjaan para anggota kelompok. Tiga implikasi penting yang terkandung dalam hal ini yaitu: (1) kepemimpinan itu melibatkan orang lain yaitu bawahan maupun pengikut, (2) kepemimpinan melibatkan pendistribusian kekuasaan antara pemimpin dan anggota kelompok secara seimbang, karena anggota kelompok bukanlah tanpa daya, (3) adanya kemampuan untuk menggunakan bentuk kekuasaan yang berbeda untuk mempengaruhi tingkah laku pengikutnya melalui berbagai cara. Pada hakikatnya, kepemimpinan merupakan proses mempengaruhi atau memberi contoh dari pemimpin kepada pengikutnya dalam upaya mencapai tujuan organisasi (Veithzal Rivai, 2003: 133).

Penyesuaian merupakan kata kunci pada kenyataan kehidupan manajerial seseorang yang menduduki jabatan pimpinan. Adalah logis apabila jika diketahui terlebih dahulu tipe-tipe kepimipinan yang dikenal dewasa ini.logis karena penyesuaian yang perlu dilakukan menyangkut perubahan dari satu tip eke tipe yang lain. Suatu perubahan hanya mungkin terjadi selama berlangsungnya situasi tertentu yang menuntut penyesuaian tersebut. Dengan demikian pembahasan atas tipologi kepemiminan menekankan salah satu tesi utama bahwa gaya kepemimpinan seseorang tidak bersifat fixed. Artinya, seseorang yang menduduki jabatan pimpinan mempunyai kapasitas untuk membaca situasi yang dihadapinya secara tepat dan menyesuaikan gaya kepemimpinannya agar sesuai dengan tuntutan yang dihadapinya, meskipun penyesuaian itu mungkin hanya bersifat sementara (Siagian,1999)

Meskipun belum terdapat kesepakatan bulat tentang tipologi kepemimpinan yang secara luas, Siagian (1999) mengemukakan lima tipe kepemimpinan, yaitu sebagai berikut:

1. Tipe autokratis

2. Tipe paternalistic

3. Tipe kharismatik

4. Tipe laissez faire, dan

5. Tipe demokratis

Tipe pemimpin tersebut diatas memiliki karakteristik yang membedakan dari satu tipe ke tipe yang lain. Banyak pendekatan yang digunakan untuk menganalisis tipe-tipe tersebut. Cara yang dapat digunakan dalam 
menganalisis berbagai karakter yang dimiliki tiap-tiap tipe ialah dengan melakukan kategorisasi karakter itu berdasarkan berikut:

1. Persepsi pemimpin tentang perannya selaku pemimpin,

2. Nilai- nilai yang dianut,

3. Sikap dalam mengemudikan jalannya organisasi,

4. Perilaku dalam memimpin, dan

5. Gaya kepemimpinan yang dominan.

a. Gaya

Kepemimpinan

Paternalistik

Gaya kepemimpinan merupakan kombinasi pengembagan pemikiran sosiologis dan pendekatan psikologis. Pangkal tolak pemikiran ini adalah 'pegawai bawahan akan bersedia kerja keras serta termotivasi melaksanakan tugas (efektif dan efisien), jika pimpinan merupakan gaya yang akomodatif'. Teori ini bertumpu pada pandangan bahan terhadap perilaku atasannya (Prof. Soebagyo Sastrodiningrat : 2002, 42) Gaya kepemimpinan adalah bagaimana seorang pemimpin melaksanakan fungsi kepemimpinannya dan bagaimana ia dilihat oleh mereka yang berusaha dipimpinnya atau mereka yang mungkin sedang mengamati dari luar (Robert, 1992). James et. al. (1996) mengatakan bahwa gaya kepemimpinan adalah berbagai pola tingkah laku yang disukai oleh pemimpin dalam proses mengarahkan dan mempengaruhi pekerja. Gaya kepemimpinan adalah perilaku dan strategi, sebagai hasil kombinasi dari falsafah, ketrampilan, sifat, sikap, yang sering diterapkan seorang pemimpin ketika ia mencoba mempengaruhi kinerja dan motivasi bawahannya (Tampubolon, 2007).

Dalam hubungannya dengan perilaku pemimpin ini, ada dua hal yang biasanya dilakukan pemimpin terhadap bawahan atau pengikutnya, yakni perilaku mengarahkan dan mendukung. Perilaku mengarahkan dapat dirumuskan sebagai sejauh mana seorang pemimpin melibatkan diri dalam komunikasi satu arah. Bentuk pengarahan dalam komunikasi satu arah ini antara lain menetapkan peranan yang seharusnya dikerjakan, tempat melakukannya bagaimana melakukannya, dan melakukan pengawasa secara ketat kepada pengikutnya. Perilaku mendukung sejauh mana seorang pemimpin melibatkan diri dalam dorangan, memudahkan interaksi, dan melibatkan pengikut dalam pengambilan keputusan.

Di dalam jurnal ini peneliti menggunakan tipe gaya kepemimpinan 
paternalistik untuk meneliti masyarakat dalam meningkatkan Sumber Daya Manusia, Adapun pengertian dari tipe kepemimpinan paternalistik ialah:

Tipe pemimpin paternalistic banyak terdapat dilingkungan masyarkat yang masih bersifat tradisional, umumnya di masyarakat agraris. Popularitas pemimpin paternalistik dilingkungan masyarakat yang demikian mungkin disebabkan oleh beberapa factor berikut :

1. Kuatnya ikatan primordial,

2. Extended family system

3. Kehidupan masyarakat yang komunalistik,

4. Peran adat istiadat yang sangat kuat dalam kehidupan bermasyarakat,

5. Masih dimungkinkannya hubungan pribadi yang intim antara seorang anggota masyarakat dan anggota masyarakat lainnya.

Persepsi seorang pemimpin paternalistic tentang perannya dalam kehidupan organaiasional dapat dikatakan diwarnai oleh harapan para pengikutnya kepada pemimpinnya. Harapan itu pada umumnya berwujud keinginan agar pemimpin mereka mampu berperan sebagai bapak yang bersifat melindungi dan yang layak dijadikan sebagai tempat bertanya dan untuk memperoleh petunjuk. Para bawahan biasanya mengharapkan seorang pemimpin paternalistic mempunyai sifat tidak mementingkan diri sendiri melainkan memberikan perhatian terhadap kepetingan dan kesejahteraan para bawahannya. Akan tetap sebaliknya, pemimpin paternalistik menghendaki kehadiran atau keberadaannya dalam organisasi tidak lagi dipertanyakan oleh orang lain. Dengan perkataanlain, legitimasi kepemimpinannya dipandang sebagai nat yang walar dan norma dengan implikasi organisasionalnya, seperti kewenangan memerintah dari mengambil keputusan tanpa harus berkonsultasi dengan para bawahannya. Singkatnya, legitimasi kepemimpinannya berarti penerimaan atas peranannya yang dominan dalam kehidupan organisasional.

Ditinjau dari segi nilai-nilai organisasional yang dianut, biasanya seorang pemimpin paternalistik mengutamakan kebenaran. Nilai demikian biasanya terungkap dalam kata-kata, seperti seruruh anggota organisasi adalah anggota satu keluarga besar atau pernyataan-pernyataan lain 
yang sejenis. Berdasarkan nilai kebersamaan itu, dalam organisasi yang dipimpin oleh orang pemimpin paternalistik kepentingan bersama dan perlakuan yang seragam terlihat menonjol pula. Artinya, pemimpin yang bersangkutan berusaha, untuk memperakukan semua orang dan semua satuan kerja yang terdapat di dalam organisasi seadil dan serata mungkin. Dalam organisasi demikian lidak terdapat penonjolan orang atau kelompok terlentu. kecuali sang pemimprn dengan dominasi keberadaannya.

Ciri-ciri kepemimpinan paternalistik adalah:

1) Pimpinan mampu berperan layaknya seorang bapak.

2) Terlalu bersifat melindungi.

3) Pengambilan keputusan pada diri pemimpin.

4) Selalu bersikap maha tahu dan maha benar.

5) Jarang memberikan kesempatan kepada bawahan untuk mengembangkan daya kreasi dan fantasi.

6) Menuntut alur atau proses pekerjaan sesuai dengan apa yang telah ada dan dijalankan.
Nilai-nilai organisasional yang dianut pemimpin paternalistik:

a) Mengutamakan kebersamaan.

b) Kepentingan bersama dan perlakuan yang seragam terlihat menonjol.

c) Hubungan atasan dengan bawahan lebih bersifat informal.

d) Pemimpin paternalistik terlalu melindungi para bawahan yang pada gilirannya dapat berakibat bahwa para bawahan itu takut bertindak karena takut berbuat kesalahan.

e) Hanya pemimpin yang mengetahui seluk beluknya organisasional, sehingga keputusan diambil oleh pemimpin dan bawahan tinggal melaksanakannya saja.

\section{Metode Penelitian}

Jenis penelitian ini adalah penelitian deskriptif, dimana penelitiannya digunakan untuk membuat kesimpulan yang lebih luas. Penelitian ini menggunakan teori kelompok yaitu dalam kepemimpinan ini memiliki dasar perkembangan yang berakar pada psikologi sosial. Teori pertukaran klasik membantunya sebagai suatu dasar yang penting bagi pendekatan teori kelompok. Teori kelompok ini beranggapan bahwa supaya kelemahan ini mencapai tujuan- 
tujuannya, maka harus terdapat suatu pertukaran yang positif diantara pemimpin dan pengikut-pengikutnya. Lokasi penelitian ini bertempat di Desa Bremi, Kecamatan Krucil, Kabupaten Probolinggo.

\section{Metode Pengumpulan Data}

Pengumpulan data adalah prosedur yang sistematik dan standar untuk memperoleh data yang diperlukan. Untuk mengumpulkan data penelitian, penulis menggunakan metode-metode antara lain :

1. Wawancara

Metode wawancara adalah suatu bentuk komunikasi verbal jadi semacam percakapan yang yang bertujuan memperoleh informasi. Jenis wawancara yang digunakan peneliti dalah wawancara terstruktur dengan membawa kerangka pertanyaan untuk disajikan kepada objek penelitian tentang gaya atau sikap dan tingkah laku pemimpin paternalistik di Desa Bremi, Kecamatan Krucil.

\section{Observasi}

Metode observasi adalah metode pengamatan dan pencatatan dengan sistematis tentang gejala-gejala yang diselidiki. Dalam penelitian jenis ini peneliti melihat atau mendengarkan kejadian yang menjadi topik penelitian.

\section{Dokumentasi}

Metode dokumentasi adalah alat pengumpulan datanya disebut form pencatatan dokumen, dan sumber datanya berupa catatan atau dokumen yang tersedia. Seperti halnya bagaimana gaya kepemimpinan di daerah tersebut dalam meningkatkan SDM.

\section{HASIL PENELITIAN}

\section{Gambaran Umum BERMI ECO PARK}

Desa Bremi, atau terkadang juga dituliskan Bermi, dikenal dengan wiata agropolitannya. Namun, berbeda dengan wisata agropolitan di Kotaa Batu yang kental dengan komoditi buahbuahannya, di sini lebih kental dengan komoditi tanaman kayu. Seperti kayu sengon, kayu balsah, ataupun jenis lainnya. Tak heran jika sepanjang perjalanan, pengunjung akan disuguhi pemandangan bagaikan sedang bertamasya di hutan belantara ala film Twilight. Selain itu, banyak pula yang menanam tumbuhan khas pegunungan seperti kubis ataupun strawberry.

Seakan tak pernah kehabisan ide untuk menyuguhkan wisata keluarga. Setelah muncul wisata Air Terjun Jaran 
Goyang di Desa Guyangan, Kecamatan Krucil. Kini di Kecamatan yang sama hadir pula sebuah wisata eco park yang menggabungkan konsep alam, pedesaan, kuliner nusantara, dan wisata edukasi dalam satu lokasi. Desa Bermi diwilayah Kecamatan Krucil Kabupaten Probolinggo kini telah diresmikan oleh PesidenJawa Power YTL Mr. Wicard. Von Harrach menjadi wisata Eco Park yang luar biasa mempesona dan dimana wisata tersebut memiliki nama Bermi Eco Park.

\section{Deskripsi Umum}

Pemimpin adalah orang yang mengemban tugas dan tanggungjawab untuk memimpin dan bisa mempengaruhi orang yang dipimpin. Sedangkan, kepemimpinan adalah suatu fungsi yang harus dilaksanakan dalam suatu organisasi, sebab kepemimpinan yang bertugas mengambil keputusan tentang hal-hal yang harus atu tidak boleh dilakukan oleh organisasi atau kelompok. Karena itu, kepemimpinan sering didefinisikan sebagai pengambilan prakarsa untuk bertindak yang menghasilkan pola interaksi yang mantap yang diharapkan untuk memecahkan masalah bersama atau mencapai tujuan bersama. Selain itu, kepemimpinan dapat pula didefinisikan sebagai kemampuan atau prses untuk mempengaruhi aktivitas atau perilaku orang lain.

Tipe Paternalistik, tipe pemipin paternalistik banyak terdapat di lingkungan masyarakat yang masih bersifat tradisional, pada umumnya di masyarakat agraris. Popularitas pemimpin paternalistic dilingkungan masyarakat yang demikian mungkin disebabkan oleh beberapa faktor berikut:

1. Kuatnya ikatan priordial

2. Extended family system

3. Kehidupan masyarakat yang komunikatif

4. Peranan adat istiadat yang sangat kuat dalam kehidupan bermasyarakat

5. Masih dimungkinkannya hubungan pribadi yang intim antara seorang anggota masyarakat dan anggota masyarakat lainnya.

Persepsi seorang pemimpin paternalistik tentang peranannya dalam kehidupan organisasional dapat dikatakan diwarnai oleh harapan para engikutnyakepadanya. Harapan itu pada umumnya berwujud keinginan agar pemimpin mereka mampu berperan sebagai bapak yang bersifat melindungi dan yang layak dijadikan sebagai tempat bertanya dan untuk memperoleh petunjuk. Para bawahan biasanya 
mengarapkan seseorang pemimpin paternalistik mempunyai sifat tidak mementingkan diri sendiri melainkan memberikan perhatian terdapat kepentingan dan kesejahteraan para bawahannya. Akan tetapi sebaliknya, pemimpin paternalistik menghendaki kehadiran atau keberadaanya dalam organisasi tidak lagi dipertanyakan oleh orang lain. Dengan perkataan lain, legitimasi kepemimpinanya dipandang sebagai hal yang wajar dan normal dengan implikasi organisasionalnya, seperti kewenangan memerintah dan mengambil keputusan tanpa harus berkonsultasi dengan para bawahannya, singkatnya, legetimasi kepemimpinanya berarti penerimaan atas peranannya yang dominan dalam kehidupan organisasionalnya.

Ditinjau di segi nilai-nilai organisasionalnya yang dianut, biasanya seorang pemimpin paternalistic mengutamakan kebersamaan. Nilai demikian biasnaya seseorang terungkap dalam kata-kata, seperti seluruh anggota organisasi adalah anggota satu keluarga besar atau pernyataan-pernyataan lain yang sejenis.berdasarkan nilai kebersamaan itu, dalam organisasi yang dipimpin oleh seorang pemimpin paternalistic kepentingan bersama dan perlakuan yang seragam terlihat menonjol pula. Artinya, pemimpin ang bersangkutan berusaha untuk memperlakukan semua orang dan semua satuan kerja yang terdapat di dalam organisasi seadil dan serata mungkin. Dalam organisasi demikian tidak terdapat penonjolan orang atau kelompok tertentu, kecuali sang pemimpin dengan dominasi keberadaannya.

Sumber Daya Manusia (SDM) adalah salah satu faktor yang sangat penting bahkan tidak dapat dilepaskan dari sebuah organisasi, baik instunsi maupun peusahaan. SDM juga merupakan kunci yang menentukan perkembangan peruahaan. Pada hakikatnya, SDM berupa manusia yang diperkerjakan di sebuah organisasi sebagai penggerak, pemikir dan perencana untuk mencapai sebuah tujuan organisasi itu. Pengertian SDM dibagi menjadi dua, yaitu pengertian mikro dan makro. Pengertian SDM secara mikro adalah individu yang bekerja dan menjadi anggota suatu perusahaan atau institusi dan biasa disebut sebagai pegawai, buruh, karyawan, pekerja, tenaga kerja dan lain sebagainya. Sedangkan pengertian SDM secara makro adalah penduduk suatu Negara yang 
sdah memasuki usia angkatan kerja, baik yang belum bekerja maupun yang sudah bekerja.

\section{Kepemimpinan Paternalistik di} Bermi Eco Park

Menurut Dr. R. Ahmad Buchari \&

Dr. Hj. Siti Marwiyah (2019) mendefinisikan Pemimpin adalah orang yang mengemban tugas dan tanggungjawab untuk memimpin dan bisa mempengaruhi orang yang dipimpin. Sedangkan, kepemimpinan adalah suatu fungsi yang harus dilaksanakan dalam suatu organisasi, sebab kepemimpinan yang bertugas mengambil keputusan tentang hal-hal yang harus atu tidak boleh dilakukan oleh organisasi atau kelompok. Karena itu, kepemimpinan sering didefinisikan sebagai pengambilan prakarsa untuk bertindak yang menghasilkan pola interaksi yang mantap yang diharapkan untuk memecahkan masalah bersama atau mencapai tujuan bersama. Selain itu, kepemimpinan dapat pula didefinisikan sebagai kemampuan atau prses untuk mempengaruhi aktivitas atau perilaku orang lain.

Ditinjau di segi nilai-nilai organisasionalnya yang dianut, biasanya seorang pemimpin paternalistic mengutamakan kebersamaan. Nilai demikian biasnaya seseorang terungkap dalam kata-kata, seperti seluruh anggota organisasi adalah anggota satu keluarga besar atau pernyataan-pernyataan lain yang sejenis.berdasarkan nilai kebersamaan itu, dalam organisasi yang dipimpin oleh seorang pemimpin paternalistic kepentingan bersama dan perlakuan yang seragam terlihat menonjol pula. Artinya, pemimpin ang bersangkutan berusaha untuk memperlakukan semua orang dan semua satuan kerja yang terdapat di dalam organisasi seadil dan serata mungkin. Dalam organisasi demikian tidak terdapat penonjolan orang atau kelompok tertentu, kecuali sang pemimpin dengan dominasi keberadaannya.

Berdasarkan hasil wawancara dapat di garis bawahi bahwa pemimpin memberikan perhatian kepada para pekerja/ bawahan selayaknya bagaimana seperti bapak kepada anaknya, beliau pun memberikan perhatian lebih dan menciptakan lingkungan yang nyaman untuk bekerja sehingga bawahan terasa nyaman untuk bekerja dan mempunyai semangat lebih untuk bekerja.

4. Karateristik

Gaya

Kepemimpinan Paternalistik

1. Benevolent Leadership 
Berdasarkan hasil studi Hofstede dan proyek GLOBE, Indonesia memiliki skor kolektivisme yang relatif tinggi. Budaya kolektivis sangat menghargai harmoni, tidak menggunakan argumen serta konflik dalam menyelesaikan perbedaan pendapat, mengayomi, melindungi dan menjunjung kesetiaan.

Hal di atas terbukti dari sikap benevolent leadership yang diterapkan oleh pemimpin di Jasa Raharja, dimana pemimpin memberikan perhatian kepada bawahan yang telah menghabiskan waktu bersama yang lama dengan sangat bijaksana, pemimpin menunjukkan perhatian kepada bawahan dan anggota keluarga bawahan, serta pemimpin berusaha memahami penyebab dari buruknya kinerja bawahan.

Pada penelitian ini pemimpin selalu berusaha untuk memenuhi kebutuhan bawahannya dan memberikan perhatian di luar jam kerja. Pemimpin juga memberikan dorongan ketika bawahan sedang menghadapi permasalahan yang sulit. Hal ini membuktikan pernyataan dari Zhao (1994) bahwa kepemimpinan paternalistik berfokus pada kebutuhan karyawan, baik di dalam maupun di luar tempat kerja, hal ini dipercaya dapat meningkatkan motivasi karyawan, mereka memusatkan perhatian pada prestasi dan kinerja sebagai wujud untuk mendapatkan pengakuan dari pemimpin.

Berdasarkan hasil wawancara dapat di garis bawahi bahwasannya pemimpin tidak ingin mempersuli bawahannya. Bahkan pemimpin juga memberikan perhatian lebih kepada bawahannya, terlebih perihal hak-hak pegawai yang harus dipenuhi. Pemimpin juga harus mendampingi bawahanya jika pegawai tersebut masih belum paham/mengerti atas pekerjaannya.

\section{Morale Leadership}

Pemimpin

paternalistik

membimbing bawahan dengan menunjukkan tingkat moralitas yang tinggi. Kepemimpinan moral adalah cerminan dari kualitas pribadi yang tinggi dalam sudut pandang karyawan. Sikap morale leadership yang ditunjukkan oleh pemimpin jasa raharja adalah pemimpin menjadi role model untuk bawahannya, pemimpin tidak mementingkan diri sendiri dan tidak menggunakan hubungan pribadi untuk mendapatkan keuntungan pribadi, pemimpin tidak menggunakan otoritas sebagai pimpinan untuk mencari hak-hak istimewa dan tidak mengakui pujian atau 
penghargaan atas prestasi bawahan untuk diri sendiri.

Hal tersebut membuktikan pernyataan Cheng (2008) yang menguraikan enam sikap dimana para pemimpin menunjukkan moral mereka: keberanian, kemurahan hati, tidak korupsi, tanggung jawab, adil dan memimpin dengan memberi contoh. Pada penelitian ini pemimpin berani dan bertanggung jawab atas permasalahan yang terjadi atau atas kelalaian bawahan. Pemimpin juga menunjukkan sebuah contoh yang baik bagi perilaku pribadi bawahan di tempat kerja.

Berdasarkan hasil wawancara dapat digaris bawahi bahwa pemimpin tidak harus menunjukkan amarah dan egonya kepada bawahannya untuk membuat bawahannya menyelesaikan pekerjaannya sesuai dengan target. Karena ketika atasan memberikan kenyamanan terhadap bawahannya maka pekerjaan yang dilakukan oleh bawahannya akan terselesaikan dengan baik dan dapat memenuhi target yang dicapai.

\section{Authoritarian Leadership}

Hasil studi Hofstede dan proyek GLOBE juga menyatakan bahwa masyarakat Indonesia memiliki dimensi budaya dengan power distance yang tinggi, hal ini berhubungan dengan sikap pemimpin yang otoriter. Dalam penelitian ini hanya sebagian kecil pemimpin yang memiliki sikap otoriter. Adapun sikap pemimpin di Jasa Raharja yang dapat disimpulkan oleh peneliti diantaranya sebagai berikut:

- $\quad$ Pemimpin yang tidak langsung menegur atau menghukum bawahannya yang tidak dapat menyelesaikan tugas dan tidak mematuhi aturan. Namun mereka tetap memberikan deadline untuk perbaikan dan membantu dalam penyelesaian masalah tersebut. Pemimpin hanya pernah mencoba mengisolasi pegawai yang sedikit bermasalah untuk membuat efek jera.

- Pemimpin menerapkan disiplin yang ketat terhadap bawahan namun tidak menggunakan cara yang keras dan otoriter. Salah satu disiplin yang dilakukan oleh pemimpin adalah disiplin target pencapaian kerja dengan melakuan evaluasi rutin harian untuk melihat pencapaian dan perbaikan. Pemimpin biasanya memberikan contoh kepada bawahannya utnuk memotivasi bawahan menjadi lebih disiplin dalam bekerja.

- $\quad$ Sebagian besar pemimpin juga masih mendengarkan pendapat bawahannya dalam proses pengambilan 
keputusan. Pemimpin juga selalu membuat suasana kerja yang nyaman dan tidak membuat bawahan merasa tertekan dalam bekerja.

$$
\text { - Pemimpin }
$$

selalu

menggunakan kalimat permintaan tolong ketika memerintah bawahan. Dengan memasyarakatkan bawahan seperti ini justru dapat membuat karyawan menjadi patuh kepada pemimpin dan merasa sangat nyaman dalam kepemimpinan beliau.

Berdasarkan hasil wawancara dapat digaris bawahi bahwa disiplin yang ketat sangat diperlukan agar untuk mencapai target dari sebuah perusahaan. Namun sebagai pemimpin harus bijak dalam menerapkan kedispilinan tersebut kepada bawahan, agar kemauan untuk menegakkan kedisiplinan tersebut senantiasa tumbuh dari bawahan itu sendiri. Hukuman yang diberikan oleh pemimpin kepda bawahan dapat memberikan efek jera dan tidak ada kesalahan yang terulang kembali.

\section{Kesimpulan}

Berbeda dengan wisata agropolitan di Kota Batu yang kental dengan komoditi buah-buahannya, di sini lebih kental dengan komoditi tanaman kayu. Selain itu, banyak pula yang menanam tumbuhan khas pegunungan seperti kubis ataupun strawberry. Seakan tak pernah kehabisan ide untuk menyuguhkan wisata keluarga. Kini di Kecamatan Krucil hadir pula sebuah wisata Eco Park yang menggabungkan konsep alam, pedesaan, kuliner nusantara, dan wisata edukasi dalam satu lokasi. Von Harrach menjadi wisata Eco Park yang luar biasa mempesona dan dimana wisata tersebut memiliki nama Bermi Eco Park.

Berdasarkan hasil studi Hofstede dan proyek GLOBE, Indonesia memiliki skor kolektivisme yang relatif tinggi. Hal di atas terbukti dari sikap benevolent leadership yang diterapkan oleh pemimpin di Jasa Raharja, dimana pemimpin memberikan perhatian kepada bawahan yang telah menghabiskan waktu bersama yang lama dengan sangat bijaksana, pemimpin menunjukkan perhatian kepada bawahan dan anggota keluarga bawahan,serta pemimpin berusaha memahami penyebab dari buruknya kinerja bawahan.Pemimpin juga memberikan dorongan ketika bawahan sedang menghadapi permasalahan yang sulit. Bahkan pemimpin juga memberikan perhatian lebih kepada bawahannya, terlebih perihal hak-hak pegawai yang harus dipenuhi. 
Hasil studi Hofstede dan proyek GLOBE juga menyatakan bahwa masyarakat Indonesia memiliki dimensi budaya dengan power distance yang tinggi, hal ini berhubungan dengan sikap pemimpin yang otoriter. Dalam penelitian ini hanya sebagian kecil pemimpin yang memiliki sikap otoriter. Pemimpin hanya pernah mencoba mengisolasi pegawai yang sedikit bermasalah untuk membuat efek jera. Pemimpin menerapkan disiplin yang ketat terhadap bawahan namun tidak menggunakan cara yang keras dan otoriter.

Salah satu disiplin yang dilakukan oleh pemimpin adalah disiplin target pencapaian kerja dengan melakuan evaluasi rutin harian untuk melihat pencapaian dan perbaikan.Pemimpin juga selalu membuat suasana kerja yang nyaman dan tidak membuat bawahan merasa tertekan dalam bekerja. Berdasarkan hasil wawancara dapat digaris bawahi bahwa disiplin yang ketat sangat diperlukan agar untuk mencapai target dari sebuah perusahaan. Hukuman yang diberikan oleh pemimpin kepda bawahan dapat memberikan efek jera dan tidak ada kesalahan yang terulang kembali.

\section{Daftar Pustaka}

Druckman, D. 1994. Nationalism, Patriotism, and Group Loyalty: A Social Psychological Perspective. Mershon International Studies Review, 38, 43-68.

Buchari Ahmad, Dr. Hj. Marwiyah Siti, M.Si. 2019. Kepemimpinan dan Kekuasaan antara Ide dan Kenyataa. Bandung. Penerbit tim komunikata.

Farera, dkk. 2011. Jurnal Pengaruh Gaya Kepemimpinan Paternalistik Terhadap Motivasi Kerja Pegawai Dinas Sosial Dan Tenaga Kerjakota Padang. Ilmu Administrasi Negara fakultas Ilmu sosial dan Ilmu Politik, Universitas Negeri Padang.

Mona Inayah, dkk. 2019. Jurnal Implementasi Gaya Kepemimpinan Paternalistik oleh Magister Manajemen fakultas ekonomi, Universitas Diponegoro.

Hutchinson, J., \& Smith, A. D. 2000. Nationalism: Critical concepts in political science. London, England: Routledge.

Kusumawardani, A. \& Faturochman. 2004. Nasionalisme Buletin Psikologi, 12(2),h.61-72. 
Jurnal Politik dan Sosial Kemasyarakatan

Vol 13 No 1 (2021) : Februari 2021

Madjid, Nurcholis Dkk. 1994. Umat

Beragama Dan Persatuan

Bangsa, PT Penebar Swadaya:

Jakarta.

Sugiono, Prof Dr. 2017. Metode Penelitian

Kualitatif. Bandung: Alfabeta. 